\title{
ESTIMATION, REALITY AND TREND OF GROUNDWATER NITRATE CONCENTRATION UNDER UNSEWERED AREA OF YOGYAKARTA CITY - INDONESIA
}

\author{
Doni Prakasa Eka Putra* \\ Department of Geological Engineering, Gadjah Mada University, Indonesia
}

\begin{abstract}
In the last two decades, urbanization has transformed Yogyakarta City expanding beyond its administrative area with about one million inhabitants. The City sited on shallow unconfined aquifer has rapidly changed without appropriate access to sanitation and piped water supply. Until now, only 9\% of the urban population is served by sewers system and less than 30\% of urban population have access to clean water which supplied by the local public water-work. Most of the urban population depend on shallow groundwater for much of their water supply. Regards to the massive used of on-site sanitation systems in the city, contamination of nitrate in shallow groundwater is predicted to occur and surveys of domestic dug wells have revealed a widespread nitrate contamination of the groundwater. Comparison of groundwater nitrate and chloride concentration from several old data and the latest data shows clearly an evidence of the increasing of nitrate concentration and nitrate leaching in the shallow groundwater under Yogyakarta City overtime. Considering the trend, it is no doubt that most of nitrate concentration under urbanized area in the Yogyakarta City will be greater than $50 \mathrm{mg} / \mathrm{L}$ in the next several years, if appropriate management action to deal with the on-site sanitation system is not conducted.
\end{abstract}

\section{Introduction}

Nitrate contamination of groundwater is already known or suspected to be a threat to health. Consequently, the limit amount of nitrate in drinking water is $50 \mathrm{mg} / \mathrm{L}(\mathrm{WHO}, 2004)$. Excessive amount of nitrate can cause acute effect of methaemoglobi-

*Corresponding author: D.P.E. PUTRA, Department of Geological Engineering, Faculty of Engineering, Gadjah Mada University, Jl. Grafika 2 Yogyakarta, 55281, Indonesia. E-mail: putra@gmail.com naemia, which commonly called as baby blue syndrome and infants less than three months old are most at risk (WHO, 2003). On the other hand, excessive nitrate is suspected to cause gastric cancer because there is possibility that a combination of nitrates and amines in the digestive tracts results in the formation of N-nitroso compounds, which are potentially carcinogenic (Clough, 1983; WHO, 2003).

The groundwater nitrate contamination in an improper urbanized area related generally to the widepractice of failure of on-site sanitation systems (Foster and Hirata, 1988, Morris et al., 1994; ARGOSS, 2001). Besides the failure of on-site sanitation system, the occurrence or concentration of nitrate contaminant in groundwater will depend on the type of settlement, population density, sanitation arrangement and sanitation behaviour (Foster and Hirata, 1988; ARGOSS, 2001).

Actually there is little nitrate in septic effluent, in fact about $88-99.6$ percent of the nitrogen in septic effluent is in form of ammonium and organic nitrogen (Whelan and Titamnis, 1982, Harrison et al., 2000). Regardless of the nitrogen form in the septic effluent, under aerobic conditions it can be highly expected that a significant percentage of this nitrogen will be oxidised to form nitrate and the remainder may be lost as ammonia gas or adsorbed as ammonium (GWMAP, 2000). Nitrate is very mobile and neither little adsorbed nor retarded in the soil and is therefore easily leached by heavy rainfall and infiltrating water. Under shallow groundwater conditions, water quality surveys of domestic wells in on-site sanitation areas have revealed a widespread nitrate contamination (Sinton, 1982; Morris et al., 1994).

The issue of groundwater contamination from wastewater disposal is a serious problem in cities of developing countries where, generally, there are 
many high dense populated and unsewered areas created by high rates of migration into cities (high population pressure). These areas are unplanned where pit latrines or septic tanks are common. In some cities, septic tanks and pit latrines are the only way to dispose sewage (unintegrated planned provision of sanitation), while groundwater is the main water drinking source (unintegrated planned provision of water supply).

For our study area, Yogyakarta City, more than $90 \%$ of the inhabitants are using on-site sanitation systems (commonly primitive septic tank system) to dispose their human waste. The reason of the onsite sanitation use is that the existing sewage system can served only less than $9 \%$ of the urban population. On the other hand, more than $70 \%$ of the population depend much of their water supply from the shallow groundwater, which easily accessed via dug wells (Putra and Azzam, 2007). Traditionally and due to limited land, the dug wells in the urban area of Yogyakarta City are commonly located closed to the septic system. It means that major population of Yogyakarta City is vulnerable to the potentially faecal coli and nitrate contamination. However, the hazards of faecal coli could be effectively avoided by boiling water before drinking. In case of water containing nitrate, Pacheco et al. (1996) have shown that boiling water is not recommended as this will concentrates the nitrate ions in solution (Pacheco et al., 2001). Therefore, it is important to identify and evaluate the groundwater nitrate contamination in Yogyakarta City, in order to protect the urban public health and the sustainability of urban development in this city.

\section{Study Area}

\subsection{Overview}

Yogyakarta City is located in the central-part of Java Island (Figure 1), and one of the most important culture city in Indonesia. Historically, Yogyakarta was founded in 1755 as a kingdom lead by the Sri Sultan Hamengkubuwono I. In 1930s, Yogyakarta was just a small town in the interior of Java with approximately 60.000 populations (Baiquni, 2004). Since 1970s accelerated by urbanization, the settlement pattern was shifting to many direction defined by main road networks and service centres. Until now, new business centres, education centres and tourism centres are growing hand in hand with new settlements without proper provision of water supply and sanitation system. Urbanization has transformed rural dwellings to become urban settlements and generated urban agglomeration area. The Yogyakarta urban agglomeration area consists of the Yogyakarta
City municipality and two regencies i.e. Sleman and Bantul with about one million inhabitants. The population density in the Yogyakarta City municipality area vary between 100-300 persons/ha, while the population density in its agglomeration area range between 10-30 persons/ha.

\subsection{Hydrogeology}

The aquifer beneath Yogyakarta City and its agglomeration area can be differentiated into two main aquifers: upper aquifer and lower aquifer (Figure 2). The lithology of aquifers is composed by an interbedded middle to coarse sands, gravels, silts, clays and lenses of breccia. In the upper aquifer, sand and gravels are to be more prevalent in the top 10 to $25 \mathrm{~m}$ (MacDonald \& Partners, 1984). The lower aquifer consists of generally coarser deposits than the upper aquifer (Hendrayana, 1993). The thickness of the upper aquifer ranges up to $45 \mathrm{~m}$ but is very variable. The average hydraulic conductivity of the aquifer system is about $8.64 \mathrm{~m} / \mathrm{d}$ (Hendrayana, 1993), with the average effective porosity of the aquifer of about $20 \%$ (Alpin Consult, 1989). The regional groundwater flow in the study area is directed from north to south, with groundwater gradient varying from $1 / 50$ in the north to $1 / 250$ in the south. The recent depth to groundwater in the study area varies between $0.32 \mathrm{~m}$ and $18 \mathrm{~m}$ with the average depth of about $5 \mathrm{~m}$ (Putra and Azzam, 2007). The hydroche-mical facies of the groundwater in the upper aquifer is predominantly $\mathrm{Ca}-\mathrm{Mg}-\mathrm{HCO}_{3}^{-}$to $\mathrm{Na}-\mathrm{Ca}-\mathrm{Mg}-\mathrm{HCO}_{3}$ water, while $\mathrm{Ca}-\mathrm{Mg}-\mathrm{Cl}-\mathrm{SO}_{4}$ water is more dominant in the lower aquifer (Setiadi 1990, Hendrayana, 1993). The average annual rainfall in the study area is approximately $2048.5 \mathrm{~mm} / \mathrm{a}$ from which about $20 \%$ infiltrates into groundwater as recharge (Putra and Azzam, 2007).

According to MacDonald \& Partners (1984), the inorganic chemical quality of the groundwater in the study area was very good for irrigation, drinking and most industrial purposes. Physicochemical characteristics of water ranged between < $100 \mu \mathrm{S} / \mathrm{cm}$ for Specific Electric Conductivity (EC) or $<70 \mathrm{mg} / \mathrm{L}$ for Total Dissolved Solid (TDS) in springs water and $600 \mu \mathrm{S} / \mathrm{cm}$ for EC or $500 \mathrm{mg} / \mathrm{L}$ for TDS in near geological boundaries of south, east and west. In fact, nitrate concentration in ground-water was commonly less than $2.8 \mathrm{mg} / \mathrm{L}$ at that time. The increase of nitrate concentration in shallow groundwater of some part Yogyakarta City was first recognized by Sudharmaji (1991). He reported that nitrate concentration of shallow groundwater of Yogyakarta City urban area in 1985s varied from 0.03 $\mathrm{mg} / \mathrm{L}$ to $12.9 \mathrm{mg} / \mathrm{L}$. After about one decade, Smith et al. (1999) reported that the nitrate concentration 


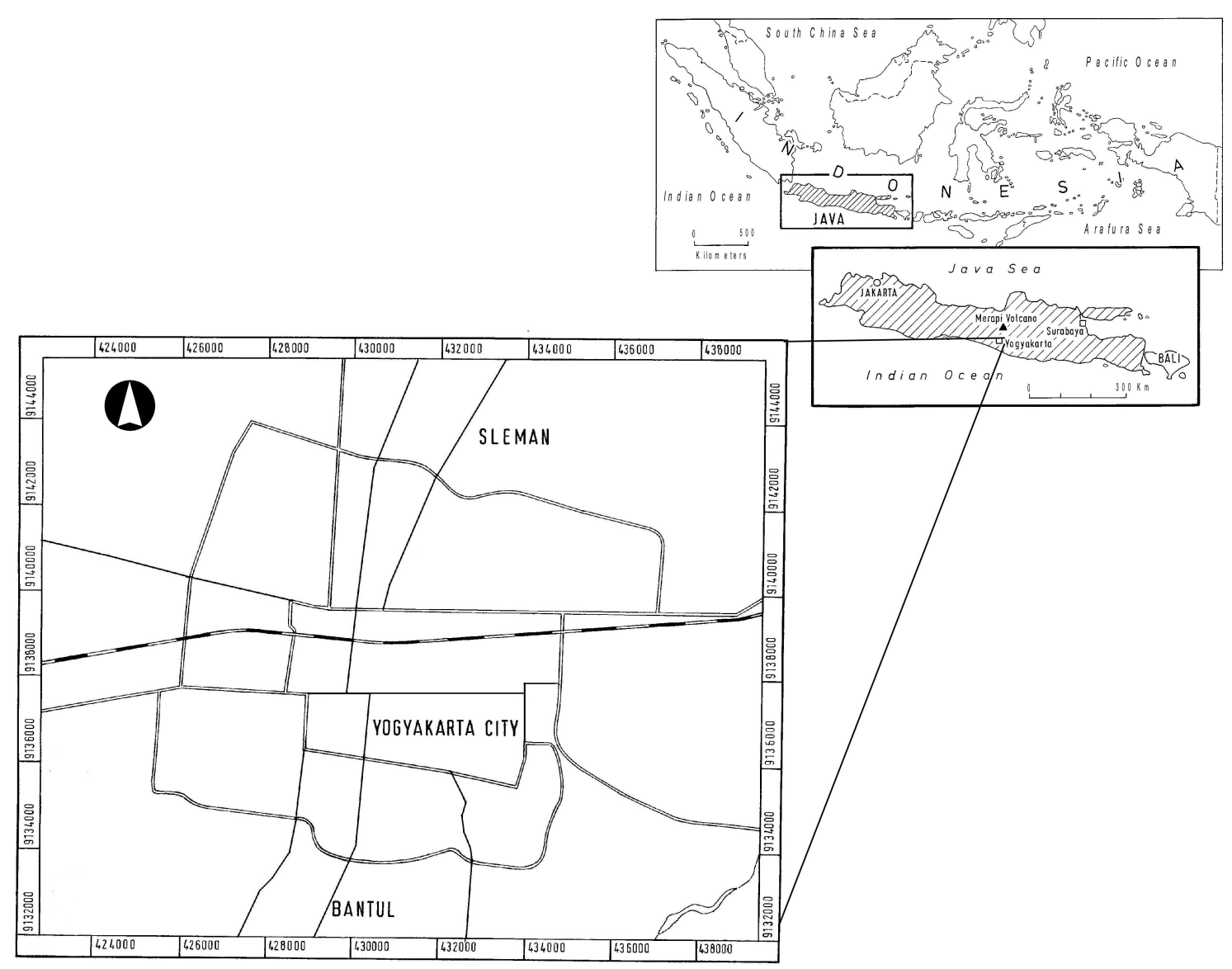

Figure 1: Location of the study are.

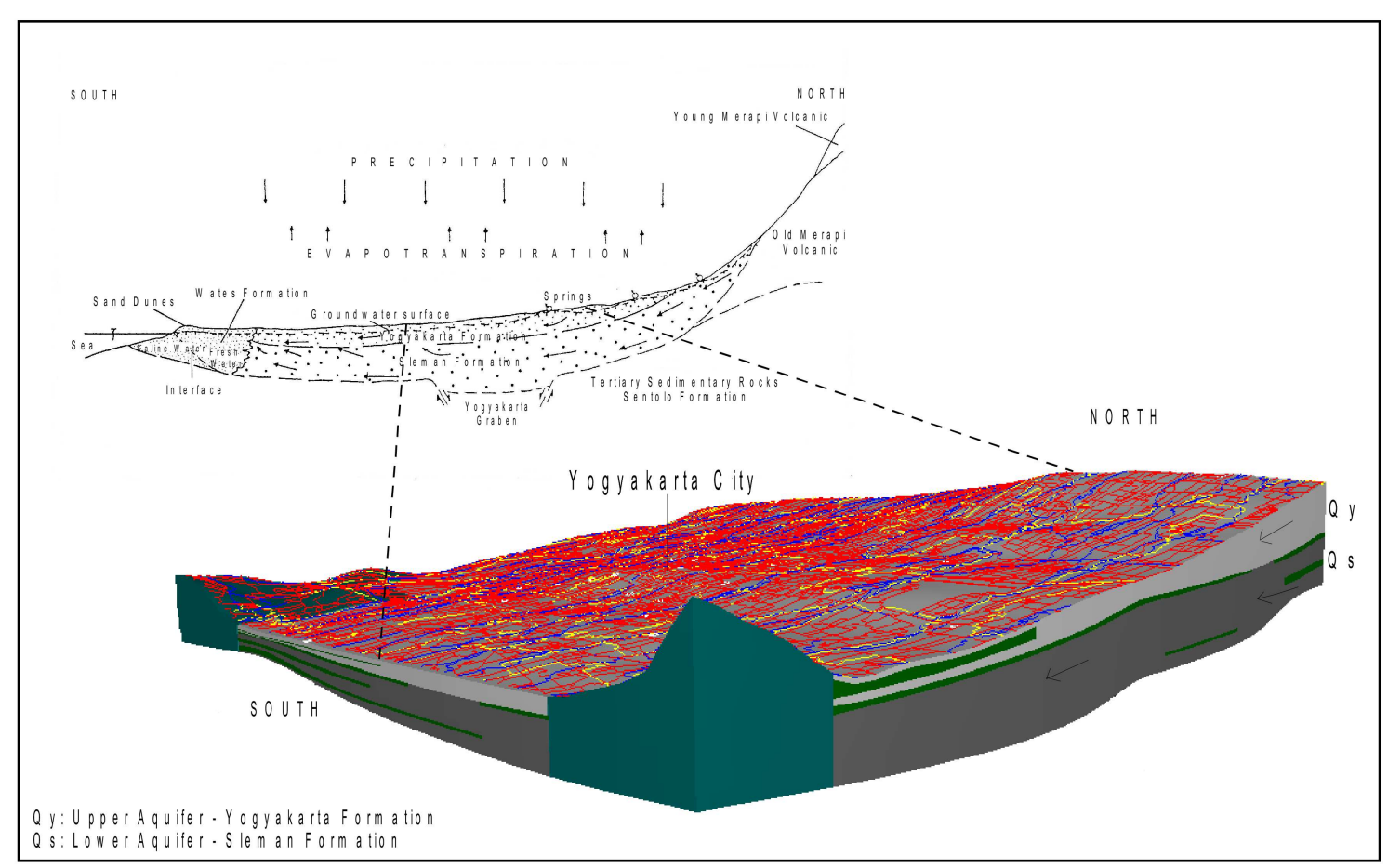

Figure 2: Hydrogeology concept of aquifer system in Yogyakarta City. 
in groundwater of Kotagede subdistrict (southeast part of Yogyakarta City) was ranged between 20 - $160 \mathrm{mg} / \mathrm{L}$ and these concentrations tend to increase most during the wet season. Furthermore, Hendrayana and Putra (2000) found that nitrate concentration in shallow groundwater of Wirobrajan subdistrict (west part of Yogyakarta City) was within the range of $1.6 \mathrm{mg} / \mathrm{L}$ and $35.4 \mathrm{mg} / \mathrm{L}$.

\section{Estimate nitrate concentration in seep- age water under unsewered areas}

For persistent and mobile contaminants like nitrate and chloride, the concentration of both contaminants in seepage water of on-site sanitation can be estimated using the following empirical equation proposed by Foster and Hirata (1988):

$$
C_{N}=\frac{1000 \cdot a_{N} \cdot D \cdot f_{N}}{0.365 \cdot D \cdot U+10 \cdot I}
$$

Where:

$C_{N}$ concentration of nitrate or chloride in recharge $(\mathrm{mg} / \mathrm{L})$

$a_{N}$ unit weight of nitrogen or chloride in excreta (kg/cap/a)

$D$ population density (cap/ha)

$f_{N}$ proportion of excreted nitrogen leached to groundwater (0.0-1.0)

$U$ non-consumptive portion of total water use (1/d/cap)

I natural rate of rainfall infiltration $(\mathrm{mm} / \mathrm{a})$

The average amount of nitrogen produced pro person is about $4-5 \mathrm{~kg}$ in excreta each year, and 2 $\mathrm{kg} / \mathrm{cap} / \mathrm{a}$ for chloride (Foster and Hirata, 1988, ARGOSS, 2001, Gajurel et al., 2003). While, the leached proportion of excreted nitrogen from on-site sanitation is related to the unsaturated zone materials (see Table 1). In principal, a value from 0.01 to 0.6 is considered to be reasonable in proportion of excreted nitrogen leached to groundwater, but in a fractured sedimentary rocks environment, a value up to 1.0 is also possible (Foster and Hirata, 1988; Jacks et al., 1998; GWMAP, 2000; ARGOSS, 2001).

Applying the above equation with similar average of non-consumptive water usage and variations of I and $f$, the estimation of nitrate concentration in seepage water from on-site sanitation in the study area can be conducted (Figure 3).

This figure indicates that urban and suburban areas in the study area are capable of producing troublesome nitrate concentration $(>50 \mathrm{mg} / \mathrm{L})$ on high nitrogen leaching condition. But on reasonable value of leaching proportion $(\mathrm{f}=0.5)$, as the dominated unsaturated zone materials in the study area is medium sand, nitrate concentration in groundwater recharge of urban and sub-urban area would be
Table 1: Possible leached proportion of excreted nitrogen from on-site sanitation (ARGOSS, 2001).

\begin{tabular}{|c|c|c|}
\hline No. & $\begin{array}{c}\text { Hydrogeological } \\
\text { Environment }\end{array}$ & $\begin{array}{c}\text { Fraction of nitrate likely to be } \\
\text { leached }\end{array}$ \\
\hline \multirow{4}{*}{ (1) } & \multicolumn{2}{|c|}{ Unconsolidated sedimentary aquifer } \\
\hline & a. clay, silt, fine sand & $\begin{array}{l}\text { Up to } 0.3 \text {; could be very low } \\
\text { especially where water table is } \\
\text { shallow and sediments clayey }\end{array}$ \\
\hline & b. fine - medium sand & about 0.3 \\
\hline & $\begin{array}{l}\text { c. medium sand - } \\
\text { gravels }\end{array}$ & $0.3-0.5$ \\
\hline \multirow{3}{*}{ (2) } & \multicolumn{2}{|c|}{ Weathered basement aquifer } \\
\hline & a. thick weathered & $\begin{array}{l}\text { Up to } 0.3 \text {; could be very low } \\
\text { especially where water table is } \\
\text { shallow and weathered material } \\
\text { clayey }\end{array}$ \\
\hline & $\begin{array}{l}\text { b. thin and/or highly } \\
\text { permeable weathered } \\
\text { layer }\end{array}$ & $0.3-0.5$ \\
\hline (3) & $\begin{array}{l}\text { Fractured consolidated } \\
\text { sedimentary aquifer }\end{array}$ & Up to 1.0 \\
\hline
\end{tabular}

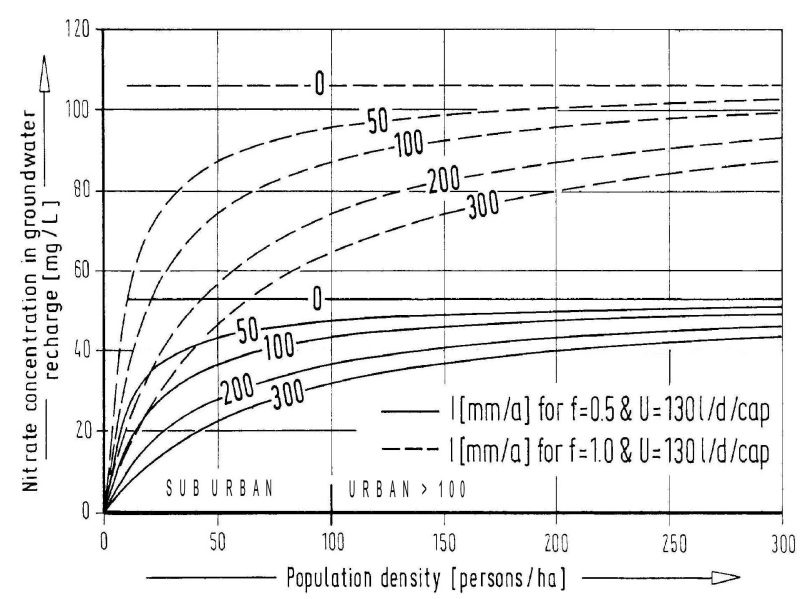

Figure 3: Range of probable nitrate concentration in the study area. 
Table 2: Groundwater nitrate concentration in Yogyakarta City overtime.

\begin{tabular}{|l|c|c|}
\hline \multirow{2}{*}{ Range of time } & Nitrate Concentration (mg/L) \\
\cline { 2 - 3 } & Interval & Mean \\
\hline $\begin{array}{l}\text { Wet Season 1970s - 1980s } \\
\text { (MacDonald \& Partners, 1984) }\end{array}$ & ND - 2.8 & 1.2 \\
\hline $\begin{array}{l}\text { Wet Season of 1985 } \\
\text { (Sudharmaji, 1991) }\end{array}$ & $0.03-12.9$ & 2.8 \\
\hline $\begin{array}{l}\text { Wet Season 1990 } \\
\text { (Hendrayana, 1993) }\end{array}$ & ND - 30 & 2.1 \\
\hline $\begin{array}{l}1994-1996^{c} \\
\text { (Smith et al., 1999) }\end{array}$ & $1.6-35.4$ & - \\
\hline $\begin{array}{l}\text { Wet Season of 1997 } \\
\text { (Hendrayana \& Putra, 2000) }\end{array}$ & $0.28-151$ & 31.5 \\
\hline $\begin{array}{l}\text { Wet Season 2005 } \\
\text { (This research) }\end{array}$ & \\
\hline $\begin{array}{l}\text { Description: } \\
\text { aYogyakarta City } \\
\text { burban fringe area of Yogyakarta City } \\
\text { 'Kotagede subdistrict; southeast part of Yogyakarta City } \\
\text { dWirobrajan subdistrict; west part of Yogyakarta City } \\
\text { eYogyakarta City and its agglomeration area }\end{array}$ \\
\hline
\end{tabular}

commonly below $50 \mathrm{mg} / \mathrm{L}$. However, the range of nitrate concentration in seepage water is more or less agreed with the last two previous studies of nitrate contamination in the study area conducted by Smith et al. (1999) and Hendrayana \& Putra (2000).

\section{Recent nitrate concentration and its spatial distribution}

Groundwater sampling for nitrate analyses was conducted on wet season 2005 and samples were taken randomly from dug wells in formal or informal sub urban and urban settlement-commercial area, agriculture and open spaces area such as grassland, forest, and natural-park of Yogyakarta. Considering that the infiltration time of the recharge water through the unsaturated zone to water table in the study area is commonly less than 3 years (Putra and Azzam, 2007). The locations of groundwater quality sampling were determined based on 2002 land use map to ensure that the groundwater quality observed recently is already reflecting the immediate human activities. The analysis of 152 groundwater samples shows that nitrate concentration of the shallow groundwater within the study area varies between $0.28-151 \mathrm{mg} / \mathrm{L}$. Comparison of the nitrate concentration in groundwater of Yogyakarta City over time is given in Table 2 .

A box plot diagram of nitrate concen-tration in shallow groundwater from various land use categories within the study area is shown in Figure 4. This diagram shows a strong relationship between land use category and nitrate concentration. The spatial distribution of nitrate concentration within the study area is given in Figure 5. Figure 4 and 5 show that not only the land use play a great role to determine the nitrate concentration in groundwater, but also another factors, such as the intrinsic hydro-

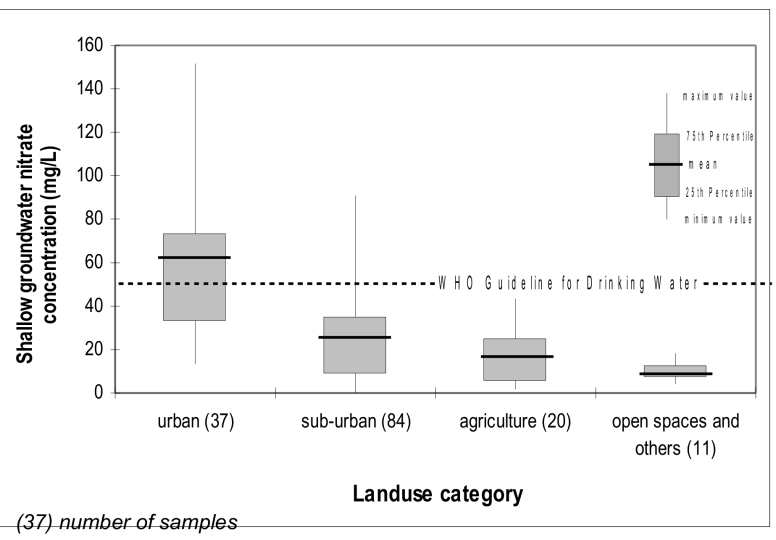

Figure 4: Boxplot diagram of groundwater nitrate concentration according to the landuse categories in the study are.

geological conditions. This can be concluded while the concentration of nitrate in groundwater under similar land use is actually varied. However, according to the land use type, the average value of the groundwater nitrate concentration is following this order; urban > sub urban > agriculture $>$ open space.

In order to prove whether groundwater nitrate of urban and sub urban area originates from faecal source, Foster and Hirata (1988), Morris et al. (1994) and ARGOSS (2001) suggested to use the ratio between nitrate and chloride concentrations. Nitrate and Chloride can be categorized as very mobile ions and are little retarded or degraded during transport (Freeze and Cherry, 1979, Appelo \& Postma, 1993, Stigter et al., 2006). Thus, if the only source of chloride and nitrate (above the background value) is indeed from domestic excreta effluent, the ratio of this ions in the underlying shallow groundwater should be similar to the average nitrogen:chloride ratio in the human excreta (2-2.5:1). These assumptions may not be valid where other wastewaters enter the disposal system (e.g. grey water) since this may contain additional chloride (Morris et al., 1994). According to ARGOSS (2001) based on their experience, if nitrate:chloride $(\mathrm{N}: \mathrm{Cl})$ ratio in groundwater ranges between $1: 1$ and $8: 1$, nitrate may originate from the faecal source.

From Figure 6, it can be seen that all nitrate in groundwater of urban areas and almost all of sub urban areas in 2005 is originated mainly from faecal sources. In fact, almost all of the urban groundwater samples show $\mathrm{N}: \mathrm{Cl}$ ratio about 2-2.5:1 similar with the ratio of nitrogen:chloride in excreta.

On the other hand, the nitrate:chloride ratio of 1985 's urban groundwater data mainly falls between the ratio $1: 1$ and 1:20, suggesting that most nitrate in urban groundwater at that time were also likely 


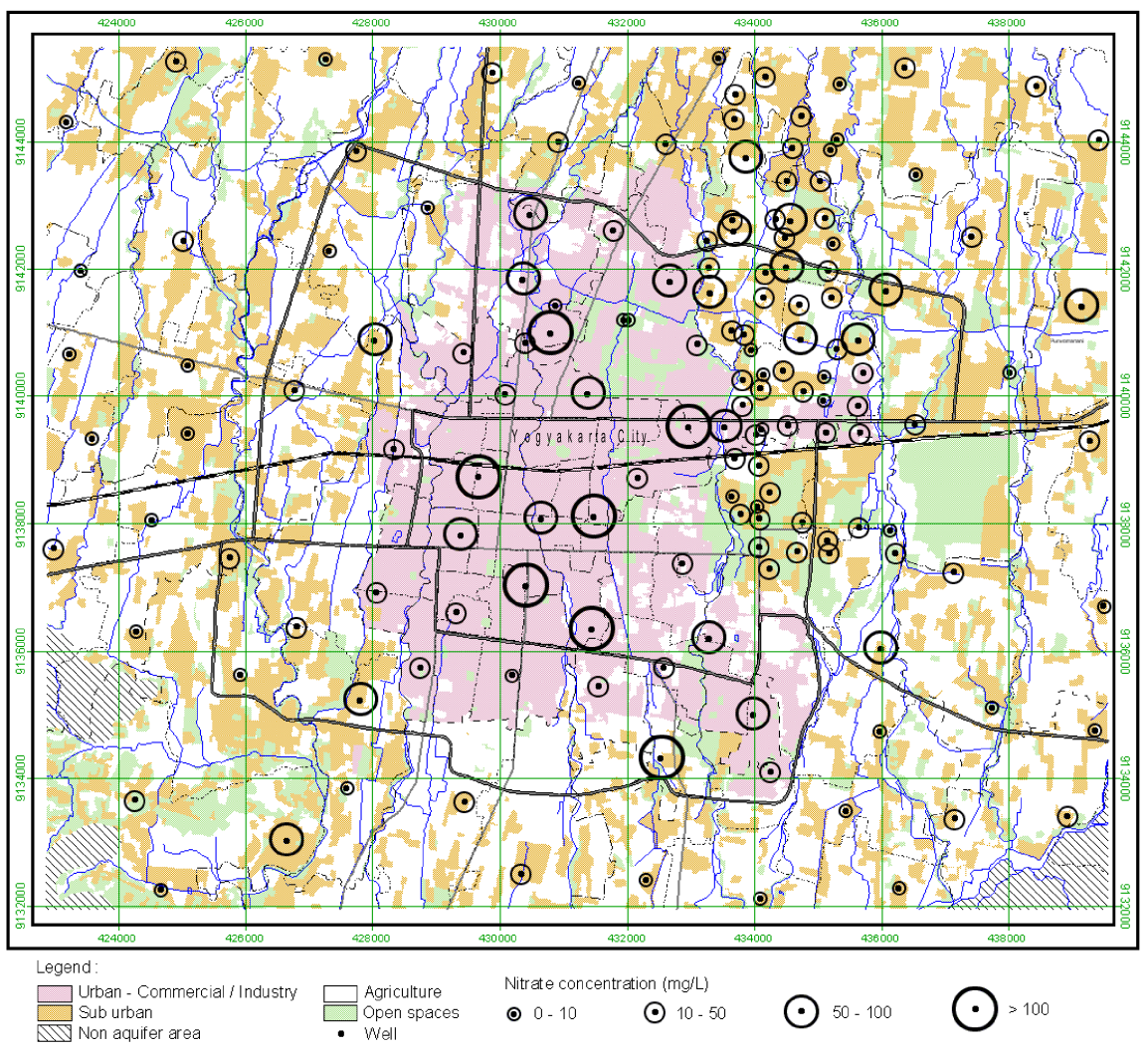

Figure 5: Composite map of groundwater nitrate concentration and land use category within the study area.

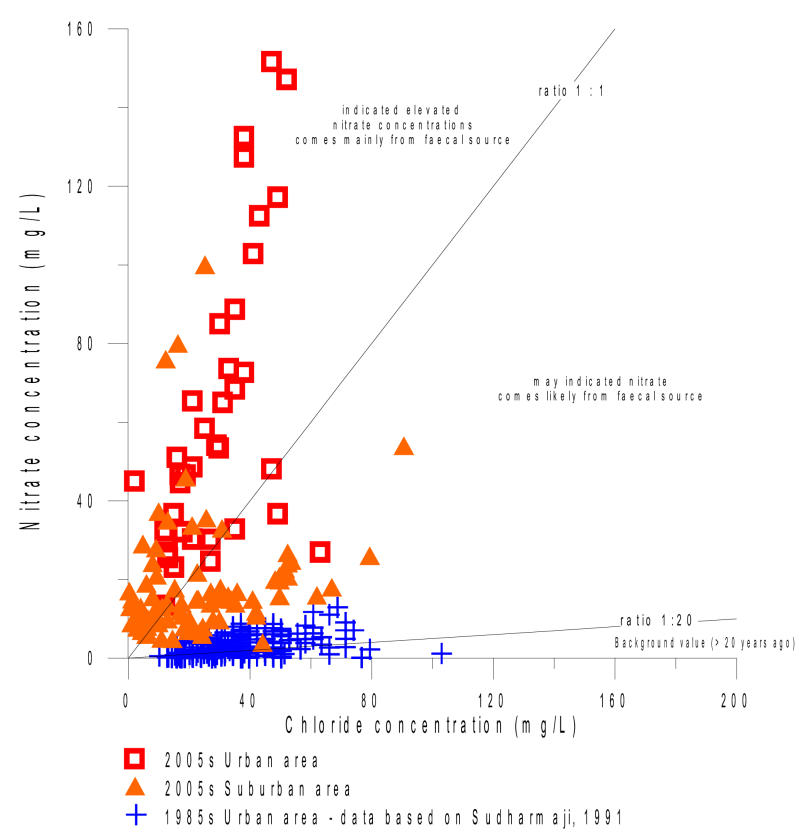

Figure 6: Diagram of nitrate versus chloride concentration in groundwater of the study area. originated from faecal sources, as predicted by Sudharmaji (1991). Besides showing the evidence of the source of elevated nitrate concentration, Figure 6 shows also the evidence of groundwater chemistry change due to increase of nitrate concentrations in urban groundwater over time. This diagram suggests that in the last 20 years, nitrate built up gradually in groundwater under urbanized area (urban/sub urban area). There are two reasons of this phenomenon; (1) the persistency of nitrate and (2) the increase of nitrate leaching rate over time.

It should be also mentioned that based on the ratio of nitrate:chloride, some samples taken from shallow groundwater under agricultural field and open spaces (incl. natural park and undeveloped area) apparently also contain nitrate which mainly comes from the faecal source. This fact may occur due to relatively fast movement of groundwater flow in the study area. Using the average hydraulic conductivity and effective porosity of the Merapi Aquifer, the groundwater flow velocity can be estimated at an average of $0.5 \mathrm{~m} / \mathrm{d}$ and thus moves averagely a bit less than $200 \mathrm{~m}$ in 1 year. Therefore, because nitrate is very mobile and moves with groundwater with little retardation or degradation over a considerable range of aquifer conditions, the observed groundwater nitrate concentrations could reflect the influ- 
ences of the upstream land use, in this case urban and/or sub urban area.

\section{Trend of nitrate leaching under unsew- ered area}

The increase of nitrate leaching may be relevant to the booming of population and urbanization process in the study area that started in the last two decades. The percentage of the nitrogen leaching to groundwater can be seen by comparing nitrate:chloride ratio in underlying shallow groundwater with the average of nitrogen:chloride ratio in excreta. The assumption of this comparison is; there is no other source of wastewater that enters to the disposal system which may contain additional chloride (Morris et al., 1994). Using this assumption, the nitrate:chloride ratios data suggest that (1) approximately $5 \%$ of the nitrogen leached to groundwater in urban setting in 1985, (2) about $25 \%$ of the nitrogen leached to groundwater in sub urban setting (new developed area) in 2005 and (3) greater than 80 $\%$ of the nitrogen leached to groundwater in urban setting (old developed area) in 2005. Thus, within 20 years, it can be concluded that leaching of nitrate from the on-site sanitation system to groundwater in unsewered - partially sewered urbanized area of the study area increased drastically from about $5 \%$ to greater than $80 \%$.

The phenomenon of high percentage of nitrogen leaching in old unsewered urbanized area is also reported by Appleyard (1995) and GWMAP (2000). Based on both studies, there are several factors which cause the increase of nitrate leaching in old developed area, which are;

1. the ammonium adsorption capacity of the soil zone may be fully utilized in older systems,

2. ammonia may be weakly adsorbed as saturated and reducing conditions occur in the soil zone under unsewered sanitations area,

3. the decrease of denitrification process in aquifer.

The first and second factor causes most ammonia from on-site sanitation reach groundwater and may subsequently be oxidized to nitrate (GWMAP, 2000). Whilst the third factor occurs due to the increase of aquifer redox potentials as the effect of urban recharge processes over a long period (Appleyard, 1995). Denitrification is known to take place when aquifer redox potentials are less than $300 \mathrm{mV}$, and when heterotrophic bacteria in presence of organic carbon existing. In the absence of organic carbon, other chemical species such as sulphides and minerals containing $\mathrm{Fe}(\mathrm{II})$ can reduce nitrate to nitrogen.
This denitrification condition has probably occurred in the shallow groundwater system of the study area about 20 years ago. At that time, the redox potentials of the upper aquifer system on the depth about $10-30 \mathrm{~m}$ was between +150 and $+200 \mathrm{mV}$, furthermore in the absence of organic carbon, Fe(II) was also presence in the system (MacDonald \& Partners, 1984). In regards to the normal $\mathrm{pH}$ range of groundwater $(\mathrm{pH}=5-8)$, dissolved iron will present as $\mathrm{Fe}(\mathrm{II})$, since $\mathrm{Fe}(\mathrm{III})$ is insoluble under these conditions (Appelo \& Postma, 1993). Based on the facts above, it is reasonable to mention that the denitrification condition in the shallow groundwater system of the study area was more appropriate 20 years ago, resulting low nitrate concentration in groundwater (see Figure 5).

Overall, it can be concluded that the older the unsewered urban area is, the higher is the nitrate leaching and the higher the nitrate concentration in groundwater will be. Furthermore, as some places of sub urban area within the study area are commonly younger than urban area, it is also reasonable that some samples from this land use setting have the ratio of nitrate:chloride in groundwater ranged between 1:20 and 1:1. This fact proves that not all nitrogen from sub urban on-site sanitation leached to groundwater and the subsurface condition beneath sub urban area can remain properly attenuate nitrate contaminant.

\section{Conclusion}

From the above result and discussion, there are some conclusions that can be drawn related to the groundwater nitrate contamination under unsewered areas in the study area. First, the estimation of nitrate concentration by applying equation proposed by Foster and Hirata (1988) reveals a rough range of values. However, it is useful for predicting the probable nitrate concentration in groundwater under unsewered condition. Second, the denser the population used the on-site sanitation system to dispose their human waste, the higher the possibility to found troublesome nitrate concentration in groundwater. Third, the older the septic systems, the higher the nitrate leaching into groundwater will be due to the decreasing capability of subsurface attenuation process. Finally, concerning the recent concentration and the trend of nitrate leaching in the groundwater of the study area, it can be predicted that following the increase of urban population, it is no doubt that most of nitrate concentration under urbanized area in the Yogyakarta City and its agglomeration area will be averagely greater than $50 \mathrm{mg} / \mathrm{L}$ in less than one decade, if appropriate management action 
to rectify the problem with on-site sanitation system is not conducted.

\section{References}

Alpin Consult (1989) Yogyakarta water supply extension project, Bedog and Karanggayam wellfields, Hydrogeology and Well Drilling, Directorate of Human Settlements, Ministry of Public Works, Goverment of the Republic Indonesia.

Appelo, C.A.J., and Postma, D. (1993) Geochemistry, groundwater and pollution. A.A Balkema, Netherland, 536 p..

Appleyard, S. (1995) The impact of urban development on recharge and groundwater quality in coastal aquifer near Perth, Western Australia. Hydrogeology Journal, 3(2): 65-75.

ARGOSS (2001) Guidelines for Assessing the Risk to Groundwater from On Site Sanitation, British Geological Survey Commisioned Report, CR/01/142, 97 pp.

Baiquni, M. (2004) Urbanization and Urban Settlement Dualism: A case study and research of Yogyakarta, Indonesia, Proceeding of International Workshop on Asian Approach Toward Sustainable Urban Regeneration, September 2004, The University of Tokyo, Japan.

Clough, P.W.L. (1983) Nitrates and gastric carcinogenesis. Environmetal Geochemistry and Health, 2-3: 91-95

Foster, S., and Hirata, R. (1988) Groundwater Pollution Risk Assessment; A Methodology Using Available Data, PAN American Center For Sanitary Engineering and Environmental Sciences (CEPIS), Lima, Peru.

Freeze, R.A., and Cherry J.A. (1979) Groundwater. Prentice-Hall, Inc., Englewood Cliffs, 604 p..

Gajurel, D.R., Li, Z., and Otterpohl, R. (2003), Investigation of the effectiveness of source control sanitation concepts including pre-treatment with Rottebehaelter. Water Science and Technology, 48(1): 111-118

GWMAP (2000) Groundwater quality under three unsewered subdivisions in Minnesota, Minnesota Pollution Control Agency, Groundwater and Toxics Monitoring Unit, Environmental Monitoring and Analysis Section, Environmental Outcomes Division, Minnesota.

Harrison, R.B., Turner, N.S., Hoyle, J.A., Krejsl, J., Tone, D.D., Henry, C.C, Isaksen, P.J and Xue, D. (2000) Treatment of septic effluent for fecal coliform and nitrogen in coarse textured soils: use of soil-only and sand filter systems. Journal of Water, Air and Soil Pollution, 124: 205-215.

Hendrayana, H. (1993), Hydrogeologie und Groundwassergewinnung Im Yogyakarta Becken, Indonesien, Dissertation, RWTH-Aachen.

Hendrayana, H. and Putra, D.P.E. (2000) Delineation of nitrate contaminant plume in Yogyakarta Urban Area, Yogyakarta, in: Proceeding of 29th IAGI (Association of Indonesian Geologist) annual convention, 21- 22 November 2000, Bandung.

Jacks, G., Sefe, F., Carling, M., Hammer, M., and Letsamao, P. (1998), Tentative nitrogen budget for pit-latrines Eastern Botswana. Journal of Environmental Geology, 38: 199-203.

MacDonald and Partners (1984) Greater Yogyakarta Groundwater Resources Study Volume 3: Groundwater, 116 p, Directorate General of Water Resources Development Project (P2AT), Ministry of Public Works, Government of The Republic of Indonesia.

Pacheco, J., Marín, L., Cabrera, A., Steinich, B., and Escolero, O. (2001): Nitrate temporal and spatial patterns in 12 water-supply wells, Yucatan, Mexico. Environmental Geology, 40(6): 708-715

Putra, D.P.E and Azzam, R. (2007) Interactions between urban development and groundwater, a case study on Yogyakarta City - Indonesia, In: Proceedings of the 16th Conference on Engineering Geology and from Forum Young Engineering Geologist, 07-10 March 2007, Bochum., German.y.

Morris B.L., Lawrence A.R., and Stuart M.E. (1994) The Impact of Urbanization on Groundwater Quality (Project Summary Report), Technical Report WC /94/56, British Geological Survey.

Setiadi, H, Mudiana,W, and Akus, U. T. (1990) Peta Hidrogeologi Indonesia 1: 100.000, Lembar 1407-5 dan Lembar 1408-2 Yogyakarta, Direktorat Geologi Tata Lingkungan, Bandung.

Sinton, L.W. (1982) A groundwater quality survey of an unsewered semi - rural area, New Zealand. Journal of Marine and Freschwater Research, 16: 317-326.

Smith G.D, Wetselaar R, Fox J.J, Van de Graff R.H.M, Moeljohardjo D, Sarwono J, Asjari W.S.R, Tjojudo S and Basuki (1999) The origin and distribution of nitrate in groundwater from village wells in Kotagede, Yogyakarta, Indonesia. Hydrogeology Journal, 7: 576689.

Stigter E.T., Ribeiro, L., and Carvalho-Dill, A.M.M. (2006) Evaluation of an intrinsic and specific vulnerability assessment method in comparison with groundwater salinisation and nitrate levels in two agricultural regions in the south of Portugal. Hydrogeology Journal, 14: 79-99.

Sudarmadji (1991) Agihan geografi sifat kimiawi airtanah bebas di Kotamadya Yogyakarta, disertasi, Universitas Gadjah Mada, Yogyakarta.

Whelan, B.R., and Titamnis, Z.V. (1982) Daily Chemical Variability of Domestic Septic Tank Effluent. Journal of Water, Air and Soil Pollution, 17: 131-139.

WHO (2003) Nitrate and Nitrite in Drinking Water; Background Document for Development of WHO Guidelines for Drinking-water Quality, World Health Organization, Geneva.

WHO (2004) Guideline for Drinking-water Quality, 3rd edition, World Health Organization, Geneva, 515 p. 